\title{
PYROPROCESS WASTE DISPOSAL SYSTEM DESIGN AND DOSE CALCULATION
}

\author{
DONGHAK KOOK ${ }^{* 12}$, DONG-KEUN CHO ${ }^{1}$, MINSOO LEE ${ }^{1}$, JONGYOUL LEE ${ }^{1}$, HEUIJOO CHOI $^{1}$, and \\ YONGSOO KIM ${ }^{2}$ \\ ${ }^{1}$ Korea Atomic Energy Research Institute \\ 1045 Daedeokdae-ro, Yuseong-gu, Daejeon, 305-353, Korea \\ ${ }^{2}$ Hanyang University \\ 222 Wangsimni-ro, Seongdong-gu, Seoul, 133-791, Korea \\ "Corresponding author. E-mail : syskook@kaeri.re.kr
}

Received January 19, 2011

Accepted for Publication May 06, 2011

PWR spent fuels produced in the Republic of Korea are expected to be recycled by pyroprocess in the long term future. Even though pyroprocess waste amounts can be smaller than that of PWR spent fuel assembly in case of direct disposal, this process essentially will produce various and unique radioactive wastes. The goals of this article are to characterize these wastes, calculate the amount of wastes, design disposal systems for each waste and evaluate the radiation safety of each system by dose assessment. The absorbed dose results of the metal and ceramic waste for the engineering barrier system (EBS) showed $2.21 \times 10^{-2} \mathrm{~Gy} / \mathrm{h}$ and $1.15 \times 10^{-2} \mathrm{~Gy} / \mathrm{h}$, which are lower than the recommended value of $1 \mathrm{~Gy} / \mathrm{h}$. These results confirmed that the newly proposed disposal systems have a safety margin for the radiation produced from each waste.

KEYWORDS : Pyroprocess, Radioactive Waste, Disposal System, Dose

\section{INTRODUCTION}

Korea has been operating four PHWRs for power generation, but it has no more plans to construct additional PHWRs because a PHWR produces more waste than a PWR [1]. Spent fuel produced from the four PHWRs has been stored in the dry silo system for the interim storage and are planned to be disposed of directly in the future. However, spent fuel produced from 17 PWRs are projected to go through a pyroprocess for recycling. This process can recycle the spent fuel as a new energy resource by retrieving the unused uranium and can reduce the requested disposal area by segregating the spent fuel into several groups for heat release and half-lives levels [2].

A pyroprocess is an electro-chemical technology that recovers the remaining valuable resources, such as uranium from PWR spent fuel, while significantly enhancing the proliferation resistance. The extraction of transuranics (TRU) in a mixed group and highly heat generating nuclides like cesium and strontium also allow the repository burden to be reduced by this process. Several sub-processes are performed in a batch mode and Fig. 1 shows this sequential flow [3] and its wastes [4].

Brief descriptions about each sub-processes [5] are as follows:

- Decladding/Voloxidation: reduces spent fuel pellets disassembled by decladding procedure to powder through high temperature volume oxidation for the next step.

- Electrolytic reduction: changes the oxidized powder into a metal form by a reducing agent.

- Electrorefining: electro-chemically extracts only uranium from the mixed metal form.

- Electrowinning: electro-chemically recovers transuranics in a mixed group and the remaining uranium from the $\mathrm{LiCl}-\mathrm{KCl}$ molten salt.

- Salt purification \& solidification: purifies the molten salts by oxidizing and precipitating the remaining TRU, rare earths (RE), and fission products (FP).

The pyroprocess, however, can not help but produce other various and unique radioactive wastes (Fig.1). The pyroprocess radioactive wastes have two main categories [6]: a short half-life but highly heat generating waste and a long half-life waste. The former consists of cesium solidification waste from process off-gas (I) and ceramic waste (I) from LiCl molten salt. Though these wastes have a high heat generating property, they can be sent to a low level disposal area after several decades cooling time because of their short half-life. The latter category consists of TRU containing metal waste, ceramic waste (II) from LiCl-KCl waste salt, and highly heat generating iodine \& technetium from process off-gas (II). 
Iodine and technetium treatment solution have not yet been determined, while metal waste and ceramic waste (II) can be directly disposed of because of their low heat generating property. All wastes produced in the pyroprocess are summarized in Table 1.

In order to evaluate the feasibility of metal waste and ceramic waste (II) disposal implementation, this article has characterized these wastes, calculated the waste amount, designed disposal systems for each waste and estimated the radiation safety of each system by dose assessment. The final evaluation results can be represented by the absorbed dose level for EBS because this level reflects the comprehensive disposal safety for radiation.

\section{CHARACTERISTICS AND AMOUNT OF DISPOSAL WASTE}

\subsection{Metal Waste}

The spent fuel cladding hull, which is produced in the early chopping and decladding steps, occupies three quarters of the metal waste amount. This waste forms 80 percent of the initial total radioactivity of metal waste but it loses radioactivity occupation down to 25 percent after 10 years pass because it mostly contains short half-life nuclides. However, this waste also includes long half-life materials like uranium and transuranics of which quantities are small; therefore, it is classified as a direct disposal waste.

The other metal wastes are noble metal impurities (anode sludge) produced in the electrorefining step and the stainless steel spacer grid disassembled from the fuel assembly. The spacer grid is not a process waste but finally added into the metal waste block.

The metal waste weight for a $10 \mathrm{MtHM}$ spent fuel pyroprocess has been calculated as $3,177 \mathrm{~kg}$ and a compacted metal waste block density as $5,701 \mathrm{~kg} / \mathrm{m}^{3}$.

For defining the radioactive source, we set the standard spent fuel with initial enrichment as $4.5 \mathrm{wt} \%$, discharged burnup as 55,000 $\mathrm{MWd} / \mathrm{MtU}$, and cooled time in a pool as 10 years. The nuclide cross-section library of $17 \times 17$ KOFA (Korean Optimized Fuel Assembly) and structural composition activation libraries, which are produced using the TRITON/KENO-VI module in the SCALE system were also used [7].

Table 1. Pyroprocess Waste Categories and Major Contents

\begin{tabular}{c|c|c|c|c|c}
\hline \multirow{2}{*}{ Items } & \multicolumn{2}{|c|}{ Short-lived Waste } & \multicolumn{3}{c}{ Long-lived Waste } \\
\hline & Off-gas I & Ceramic I & Off-gas II & Metal & Ceramic II \\
\cline { 2 - 6 } & & $(\mathrm{LiCl})$ & & & $\mathrm{LiCl}+\mathrm{KCl})$ \\
\hline Major Content & $\mathrm{Cs}$ & $\mathrm{Cs}, \mathrm{Sr}$ & $\mathrm{I}, \mathrm{Tc}$ & $\mathrm{U}, \mathrm{TRU}$ & $\mathrm{RE}, \mathrm{TRU}$ \\
\hline Amount (kg) & 318.7 & $2,845.7$ & 455.5 & $3,136.4$ & 664.9 \\
\hline Management & Storage & Storage & Not decided & Disposal & Disposal \\
\hline
\end{tabular}

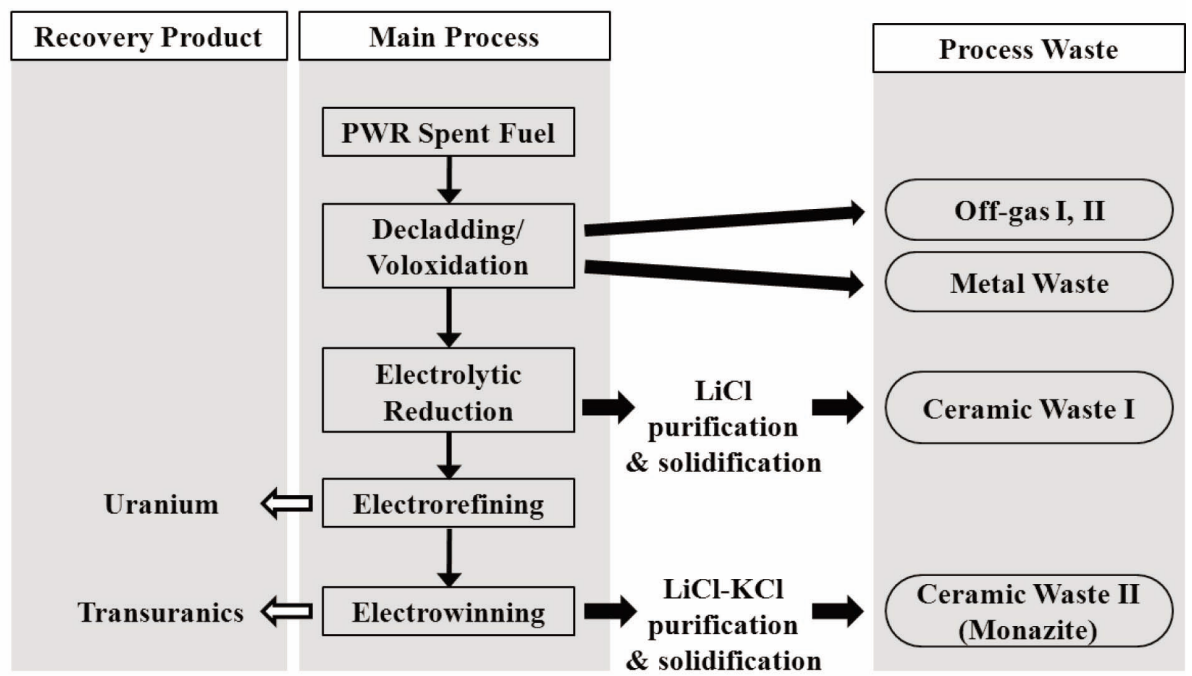

Fig. 1. Pyroprocess Flow Chart and Waste. 


\subsection{Ceramic Waste (II)}

There are two ceramic wastes from the pyroprocess, but only $\mathrm{LiCl}-\mathrm{KCl}$ waste salt is considered for direct disposal waste. It is produced in the last stage of the electrowinning step [8]. It contains unfiltered transuranics in the electrowinning step and the remaining nuclides like cesium, strontium and barium in the electrolytic reduction step. Rare earth nuclides are the main ceramic waste (II) component because only a little is removed in the former process steps. Even though rare earth nuclides are popular in ceramic waste (II), ceramic waste (II) is classified as a direct disposal waste because of other small amounts of long half-life nuclides.

The nuclide amount weight of ceramic waste (II) was calculated as $137.26 \mathrm{~kg}$ in oxidized form. These nuclides are mixed with a ceramic binder material which has four times the volume of the nuclide amount into a monazite ceramic waste form [9]. The total ceramic waste (II) weight, therefore, is $686.3 \mathrm{~kg}$, and it has a density of $3,571 \mathrm{~kg} / \mathrm{m}^{3}$.

For the initial 10 years, promethium-147 occupies the main radioactivity of ceramic waste (II), and after 10 years strontium-90 prevails in the remaining period. This change is shown in Fig. 2.

\section{DISPOSAL SYSTEM DESIGN}

Both disposal systems consist of a waste block, waste can, disposal canister and engineering barrier system. The waste can is for containing waste and sealing it, the disposal canister is for radiation shielding and the engineering barrier system is for prevention of ground water intrusion and radionuclide release in case of accident.

\subsection{Metal Waste Disposal System Design}

The conceptual diagram of the metal waste disposal system [10] is shown in Fig. 3.

Metal waste could be made in an ingot form or a compaction form. We preferred the latter because its manufacturing process and management are simpler than the former. Metal waste produced in the pyroprocess will be compressed into a disk cylinder type block. A metal

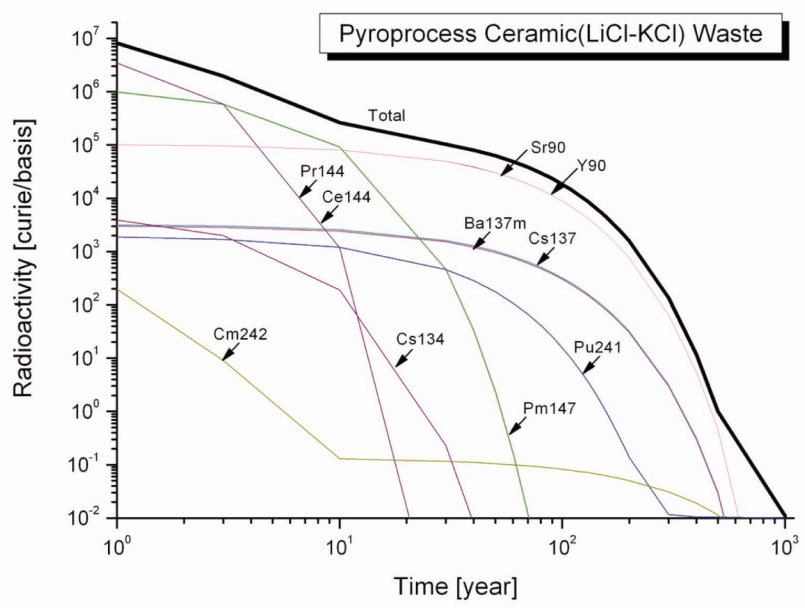

Fig. 2. Ceramic Waste Radioactivity Changes.

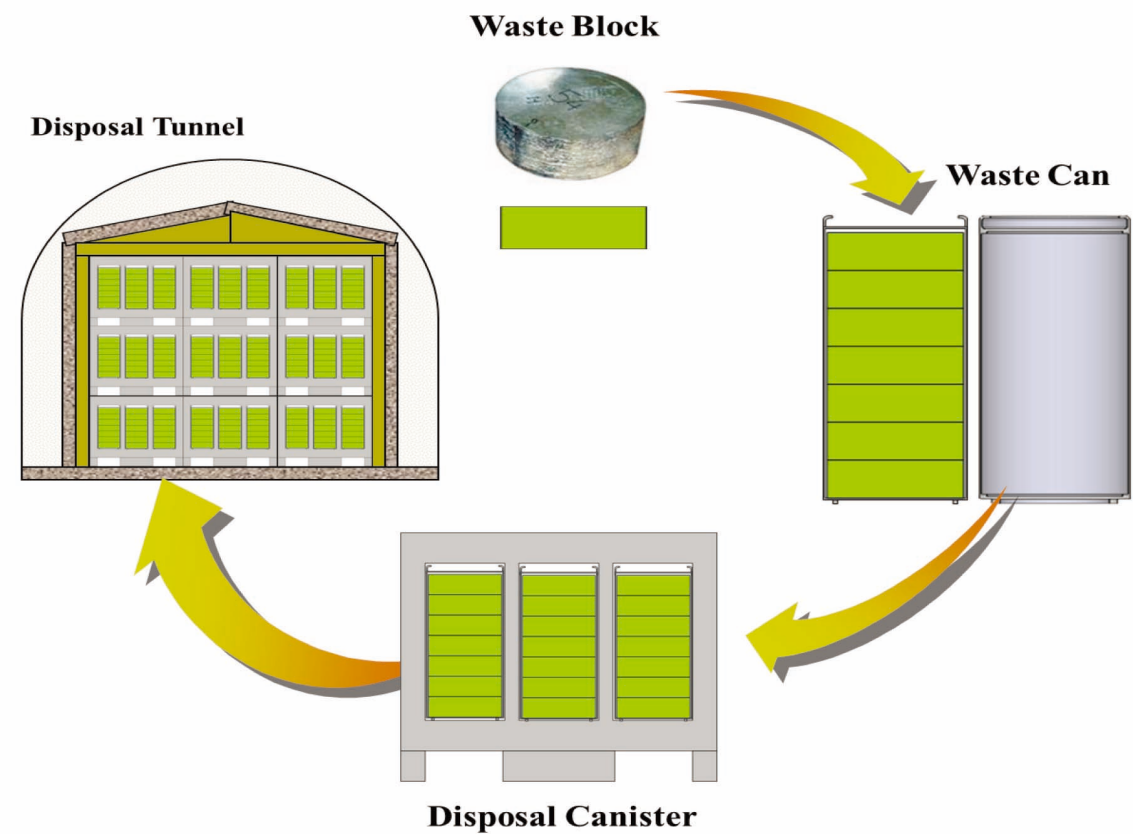

Fig. 3. Metal Waste Disposal System Concept Diagram. 
waste block weighs $40.3 \mathrm{~kg}$, its diameter is $0.3 \mathrm{~m}$, and its height is $0.1 \mathrm{~m}$. These values were determined considering convenient treatment. For a $10 \mathrm{MtHM}$ spent fuel pyroprocess, 79 metal waste blocks will be produced. A waste can is made of stainless steel 304L with $0.005 \mathrm{~m}$ thickness and it can contain seven metal waste blocks with sealing. A disposal canister, MDP (Metal waste Disposal Package), which is made of reinforced concrete can contain nine waste cans. Its dimension is $1.3(\mathrm{~L})$ x $1.3(\mathrm{~W}) \times 1.22(\mathrm{H})$ $\mathrm{m}$. It has $0.15 \mathrm{~m}$ thickness in both the top and bottom positions and $0.1 \mathrm{~m}$ thickness in the lateral position for radiation shielding, and it also has a leg part in the bottom for fork lift operations in the tunnel.

According to a reinforced concrete density of 2,400 $\mathrm{kg} / \mathrm{m}^{3}$, a disposal canister weighs $3,520 \mathrm{~kg}$ without wastes and about $6,000 \mathrm{~kg}$ with wastes. This canister concept is shown in Fig. 4.

(a)

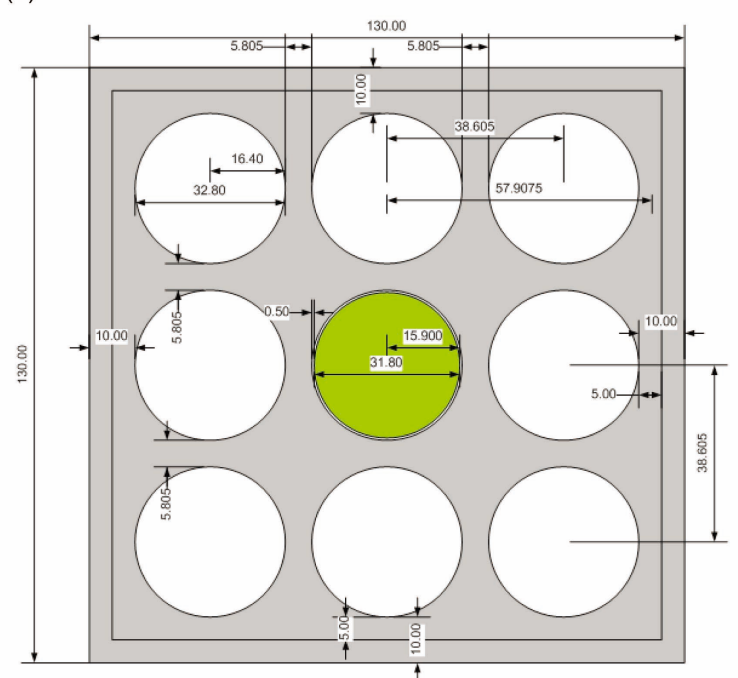

(b)

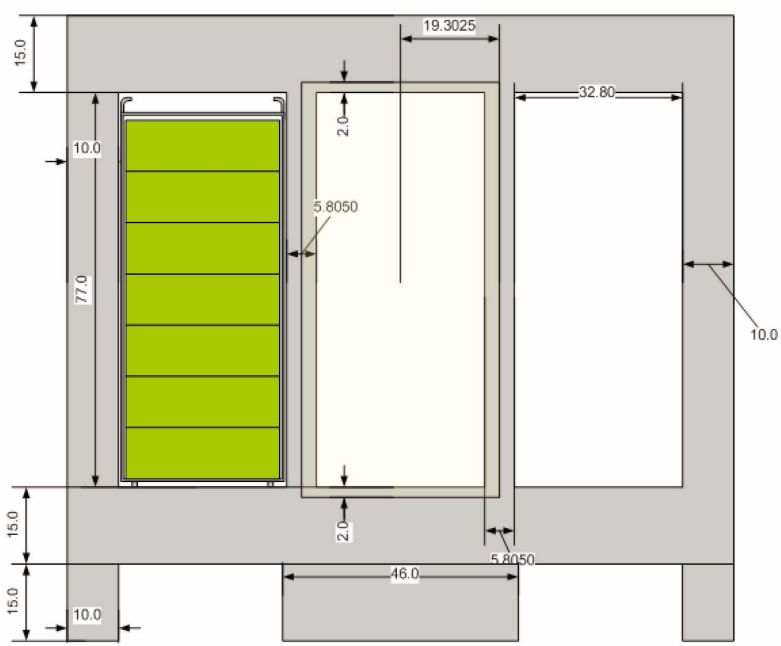

Fig. 4. Metal Waste Disposal Canister Concept.
9 MDPs will be piled up in a $3 \times 3$ array in a MDT (Metal waste Disposal Tunnel). Because of the tunnel's height limitation the MDP cannot be piled up in more than three layers. The engineering barrier system, which consists of a $0.1 \mathrm{~m}$ thick bentonite layer and an additional $0.1 \mathrm{~m}$ thick concrete layer over the bentonite layer, covers a 9 MDPs pile for a more stable disposal condition. This concept is shown in Fig. 5.

\subsection{Ceramic Waste Disposal System Design}

The conceptual diagram of the ceramic waste disposal system is shown in Fig. 6.

A solidified ceramic waste cylinder block has a 0.26 $\mathrm{m}$ diameter and a $0.25 \mathrm{~m}$ height. For a $10 \mathrm{MtHM}$ spent fuel pyroprocess, the ceramic waste will be produced as about 14.5 blocks.

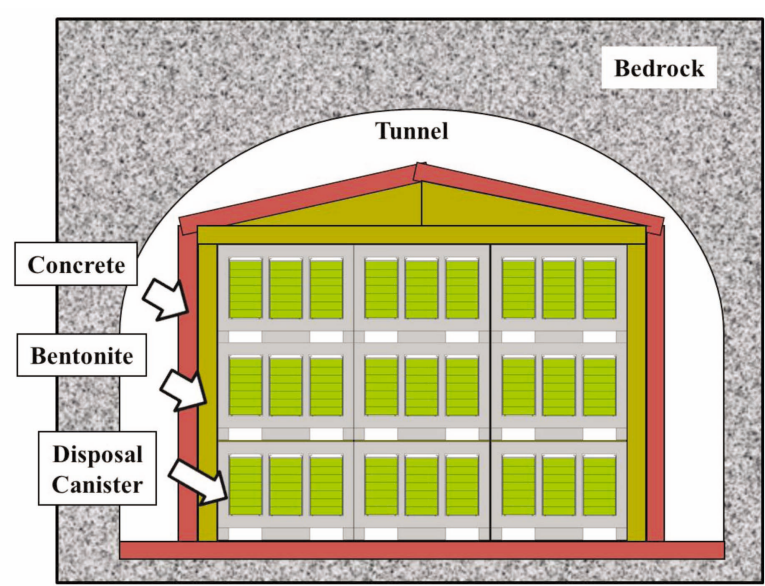

Fig. 5. Metal Waste Disposal Tunnel Concept.

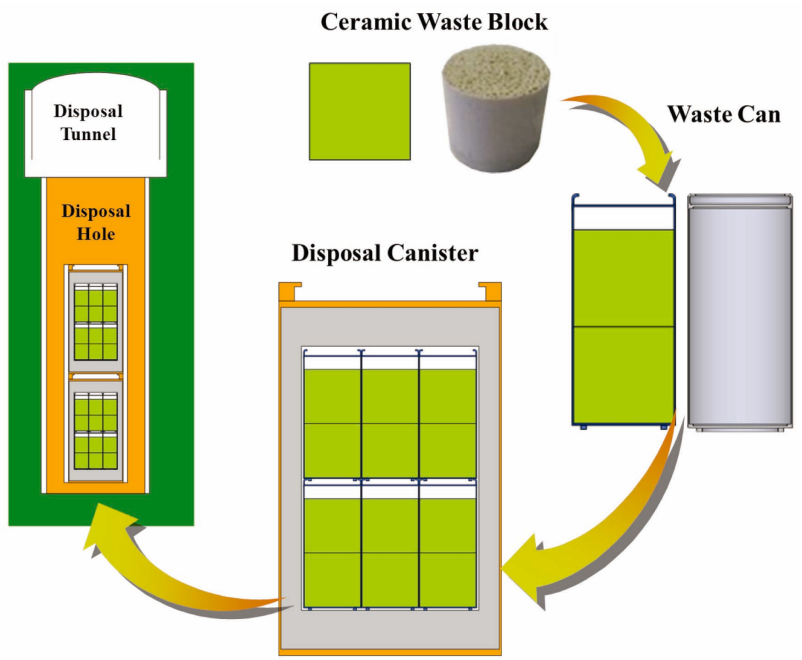

Fig. 6. Ceramic Waste Disposal System Concept Diagram. 
Two waste blocks can be inserted in a ceramic waste can. This can has a $0.267 \mathrm{~m}$ diameter and a $0.608 \mathrm{~m}$ height and has enough empty space (13\%) at the top for the gases generated from the ceramic waste. This can is made of stainless steel $304 \mathrm{~L}$ and has a $0.005 \mathrm{~m}$ thickness at the top and bottom and $0.0034 \mathrm{~m}$ at the lateral region. A disposal canister for ceramic waste can contain a total of 14 waste cans in a double layer. This concept is shown in Fig. 7. A cast iron wall with $0.18 \mathrm{~m}$ thickness at the top

(a)

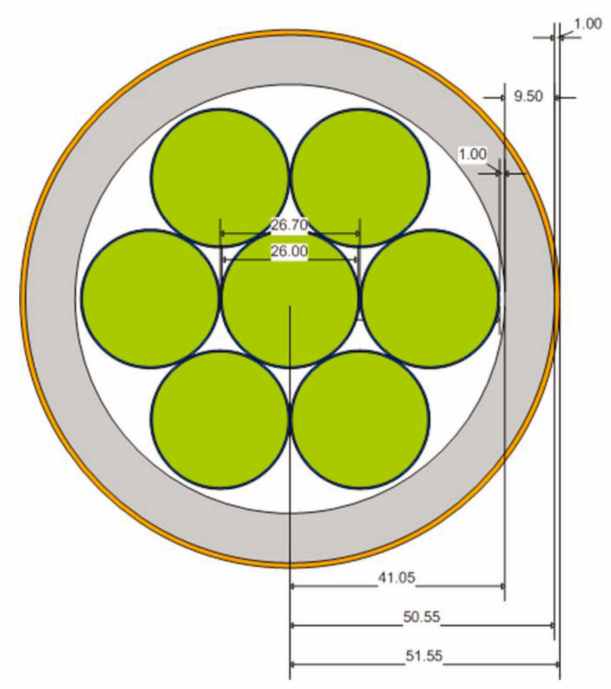

(b)

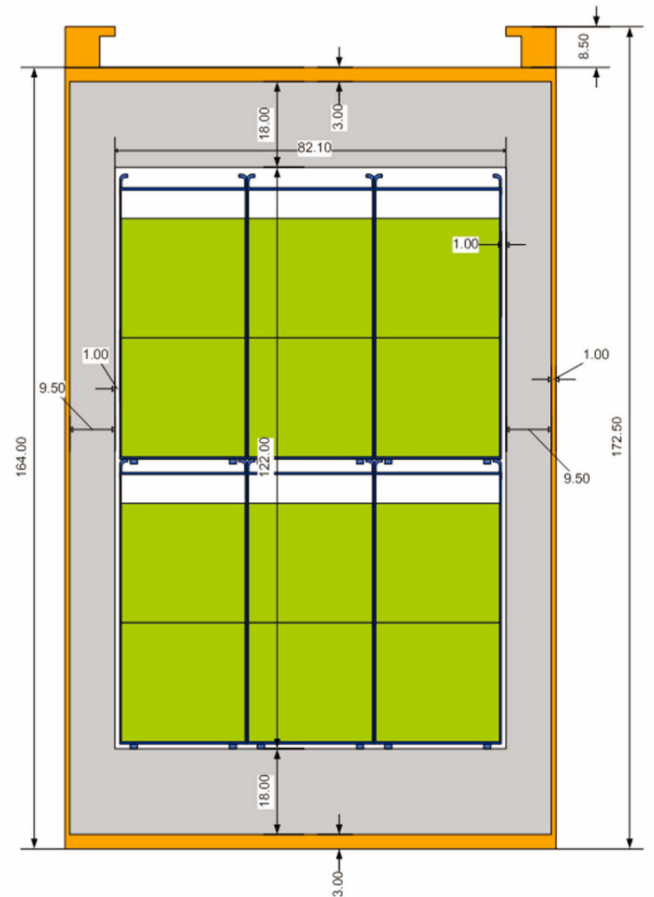

Fig. 7. Ceramic Waste Disposal Canister. and bottom and $0.095 \mathrm{~m}$ thickness at the lateral region is designed at the inner side of the canister for shielding purposes. Copper coating with $0.03 \mathrm{~m}$ thickness at the top and bottom and $0.01 \mathrm{~m}$ thickness at the lateral region is added in order to prevent corrosion in the disposal environment.

The engineering barrier system for ceramic waste is similar to the KRS-V1 disposal barrier system [11]. This consists of a vertical disposal hole, bentonite blocks around the disposal canister, and bedrock in the outer region as in Fig. 8 .

\section{RADIATION SAFETY EVALUATION FOR EBS}

\subsection{Metal Waste Disposal System Dose Calculation}

Detailed metal waste weights for each species were calculated and are shown in Table 2 in order to define the metal waste nuclide composition over 40 years after the reactor discharge, which includes 10 years for the initial cooling time in a reactor pool and 30 years for the interim storage period between the pyroprocess and final disposal

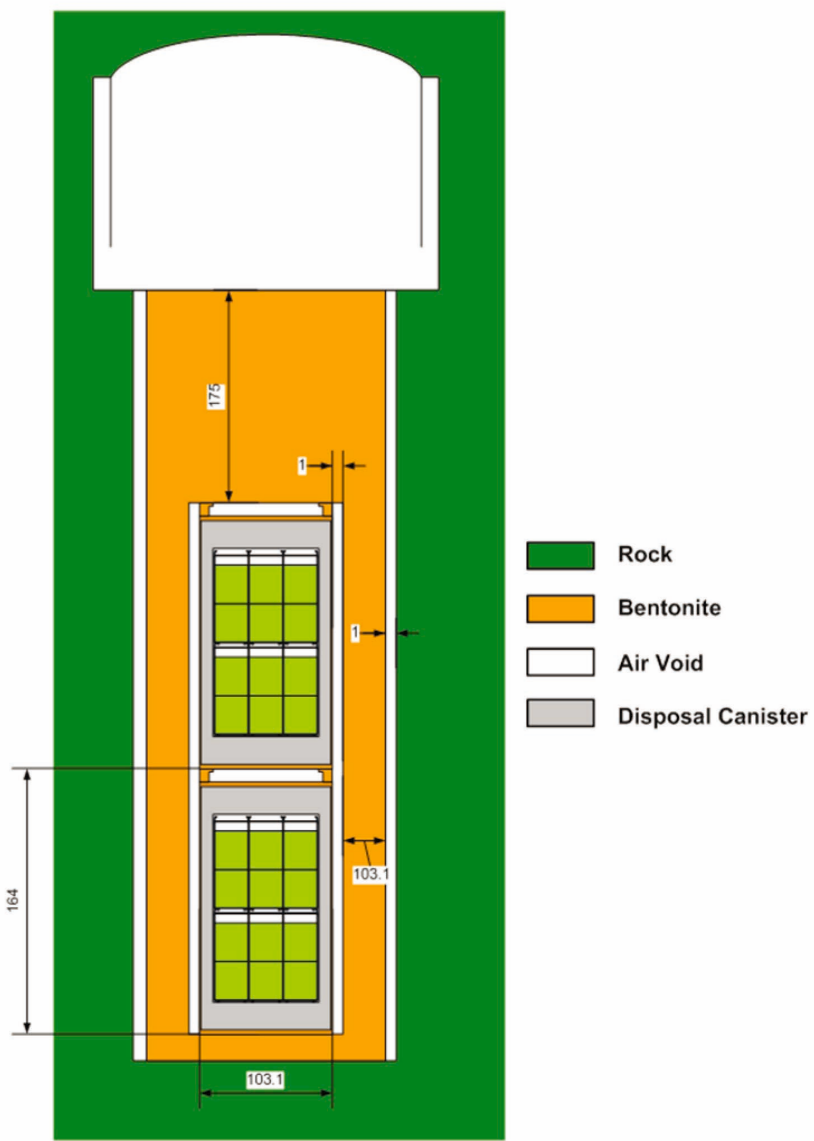

Fig. 8. Engineering Barrier System of Ceramic Waste. 
[12]. The calculation results of the material composition show that materials based on zirconium and stainless steel occupy almost $96 \%$ of the metal waste weight. Therefore, the assumption that these two materials are the whole component of the metal waste was reasonably accepted because the material composition calculation for all the waste components is very complicated and it does not drastically affect the dose result in this case. The normalized material composition for the metal waste is shown in Table 3 and was applied to the MCNPX [13] data card input.

The total photon and neutron rate for a waste can that contains seven metal waste blocks was calculated as 5.11 $\mathrm{x} 10^{11}$ (photons/s) and $7.77 \times 10^{2}$ (neutrons/s) in total for the 44 energy groups using ORIGEN-ARP 5.0. The Fluxto-Dose conversion factor of the ICRP-74 recommendation was used for dose conversion. By using the above material composition and radiation sources as inputs on the MCNPX, the dose calculation for a metal waste can was performed and the results for each direction are shown in Table 4.

Table 2. Metal Waste Species and Weight

\begin{tabular}{l|c|c}
\hline \multicolumn{1}{c|}{ Item } & Mass [kg] & Fraction \\
\hline Zr-clad & $2.54 \mathrm{E}+03$ & 0.7503 \\
\hline Zr-grid & $3.67 \mathrm{E}+02$ & 0.1084 \\
\hline SUS321 Top End Piece & $1.49 \mathrm{E}+02$ & 0.0440 \\
\hline SUS321 Bottom End Piece & $1.28 \mathrm{E}+02$ & 0.0378 \\
\hline U+TRU+FP & $6.15 \mathrm{E}+01$ & 0.0182 \\
\hline SUS302 End Cap & $5.57 \mathrm{E}+01$ & 0.0165 \\
\hline Inconel 718 Top End Piece & $3.51 \mathrm{E}+01$ & 0.0104 \\
\hline Inconel 718 grid & $3.17 \mathrm{E}+01$ & 0.0094 \\
\hline SUS302 guide sub & $1.70 \mathrm{E}+01$ & 0.0050 \\
\hline \multicolumn{1}{c|}{ Total } & $3.38 \mathrm{E}+03$ & 1.0000 \\
\hline
\end{tabular}

The neutron dose was very low because the possible major neutron sources like uranium and transuranics were very little in the metal waste. For the photon dose, an Inconel 718 spacer grid was the main gamma source. Dose calculations for the MDP that contained nine metal waste cans was performed and the results are also shown in Table 4. Dose amounts from the MDP concrete wall were similar to that of a metal waste can. Considering that the half value layer of concrete is around 0.045-0.06 $\mathrm{m}$, this result is reasonable for a $0.1 \mathrm{~m}$ concrete MDP wall thickness. Different from the dose calculation of a can and a canister, the absorbed dose is usually used for an engineering barrier like bentonite or bedrock in order

Table 3. Normalized Metal Waste Composition

\begin{tabular}{|c|c|c|c|}
\hline Item & Nuclide & Sub-fraction & Total-fraction \\
\hline & \multicolumn{2}{|c|}{ Total } & 1.00000 \\
\hline \multirow{4}{*}{$\mathbf{Z r}$} & \multicolumn{2}{|c|}{ sub-total } & 0.91300 \\
\hline & $\mathrm{Fe}$ & 0.0050 & 0.00457 \\
\hline & $\mathrm{Sn}$ & 0.0159 & 0.01452 \\
\hline & $\mathrm{Zr}$ & 0.9791 & 0.89392 \\
\hline \multirow{9}{*}{ SUS321 } & \multicolumn{2}{|c|}{ sub-total } & 0.08700 \\
\hline & $\mathrm{Fe}$ & 0.6714 & 0.05841 \\
\hline & $\mathrm{C}$ & 0.0008 & 0.00007 \\
\hline & $\mathrm{Cr}$ & 0.1800 & 0.01566 \\
\hline & $\mathrm{Mn}$ & 0.0200 & 0.00174 \\
\hline & $\mathrm{Ni}$ & 0.1000 & 0.00870 \\
\hline & $S$ & 0.0003 & 0.00003 \\
\hline & $\mathrm{Si}$ & 0.0075 & 0.00065 \\
\hline & $\mathrm{Ti}$ & 0.0200 & 0.00174 \\
\hline
\end{tabular}

Table 4. Dose Calculation Result for Metal Waste Disposal System

\begin{tabular}{|c|c|c|c|c|c|}
\hline \multirow{2}{*}{ Items } & \multirow{2}{*}{ Location } & \multicolumn{3}{|c|}{ Dose } & \multirow{2}{*}{ Unit } \\
\hline & & Gamma & Neutron & Total & \\
\hline \multirow{3}{*}{ Waste can } & Top & $8.08 \mathrm{E}+01$ & 3.67E-05 & $8.08 \mathrm{E}+01$ & \\
\hline & Side & $1.11 \mathrm{E}+02$ & 6.07E-05 & $1.11 \mathrm{E}+02$ & $\mathrm{mSv} / \mathrm{h}$ \\
\hline & Bottom & $9.39 \mathrm{E}+01$ & $4.36 \mathrm{E}-05$ & $9.39 \mathrm{E}+01$ & \\
\hline \multirow{3}{*}{ MDP } & Top & $1.30 \mathrm{E}+02$ & $3.04 \mathrm{E}-05$ & $1.30 \mathrm{E}+02$ & \\
\hline & Side & $2.20 \mathrm{E}+02$ & $4.41 \mathrm{E}-05$ & $2.20 \mathrm{E}+02$ & $\mathrm{mSv} / \mathrm{h}$ \\
\hline & Bottom & $1.62 \mathrm{E}+02$ & 4.34E-05 & $1.62 \mathrm{E}+02$ & \\
\hline EBS & & $2.21 \mathrm{E}-02$ & $5.09 \mathrm{E}-10$ & $2.21 \mathrm{E}-02$ & Gy/h \\
\hline
\end{tabular}


to estimate how the barrier could not help but absorb the radiation energy from the waste. The adsorbed dose of the engineering barrier system from the metal waste was conservatively calculated for the most inner $0.01 \mathrm{~m}$ bentonite layer. Usually, $1 \mathrm{~Gy} / \mathrm{h}$ value is the recommended limit for the bentonite engineering barrier because a higher radiation energy than this could cause radiolysis of bentonite [14]. The adsorbed dose result in Table 4 shows that the engineering barrier system of metal waste has enough margin for this. Fig. 9 shows the MDPs and engineering barrier modeling in the MCNPX.

(a)

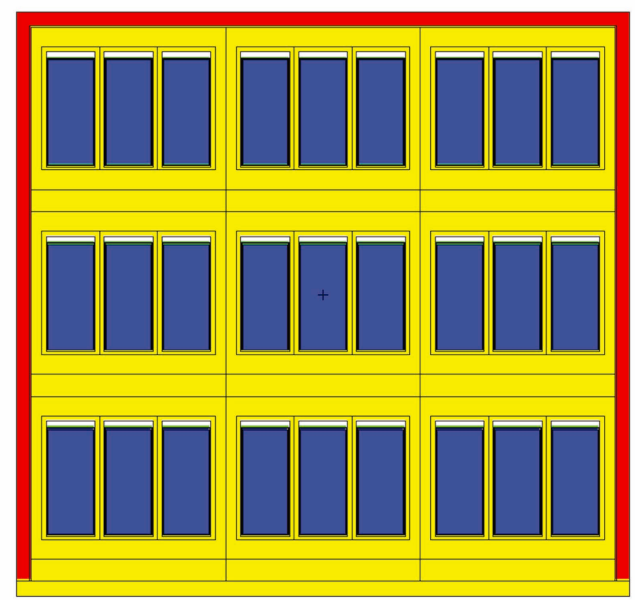

(b)

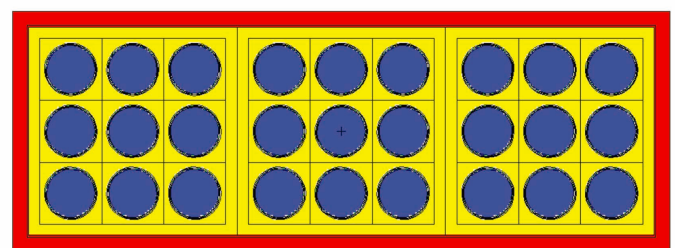

Fig. 9. MDPs and Engineering Barrier Modeling for Metal Waste.

\subsection{Ceramic Waste Disposal System Dose Calcu- lation}

The total photon and neutron rate for a waste can that contains two ceramic waste blocks was calculated as $1.51 \times 10^{13}$ (photons/s) and $1.079 \times 10^{3}$ (neutrons/s) in total for the 44 energy groups using the ORIGEN-ARP 5.0. The same flux-to-dose conversion factor applied for the metal waste was used again for the dose conversion.

Dose calculations for a ceramic waste can and a disposal canister was performed and the results for each case are shown in Table 5. The results show that the surface doses of a waste can are very high for each direction, but the disposal canister is well shielded because of the cast iron and copper shielding thickness. The absorbed dose in the ceramic waste engineering barrier as in the metal waste case was calculated for the most inner $0.01 \mathrm{~m}$ bentonite layer and is also shown in Table 5. This result shows that the engineering barrier system of the ceramic waste has enough margin for the radiolysis threshold value.

\section{CONCLUSION}

This article classified the pyroprocess wastes, made a decision about which waste was to be disposed of, characterized its properties and quantitatively calculated its amount. Based on this information, a new disposal system for these wastes was designed and dose calculations were performed to evaluate the radiation safety of the designs. The results showed that the newly designed disposal systems have enough radiation safety margin for the disposal engineering barrier.

\section{ACKNOWLEDGEMENT}

This work has been carried out under the Nuclear R\&D Program supported by Ministry of Education Science and Technology (MEST), Korea.

Table 5. Dose Calculation Result for Ceramic Waste Disposal System

\begin{tabular}{|c|c|c|c|c|c|}
\hline \multirow{2}{*}{ Items } & \multirow{2}{*}{ Location } & \multicolumn{3}{|c|}{ Dose } & \multirow{2}{*}{ Unit } \\
\hline & & Gamma & Neutron & Total & \\
\hline \multirow{3}{*}{ Waste can } & Top & $2.4049 \mathrm{E}+02$ & 5.9679E-05 & $2.4049 \mathrm{E}+02$ & $\mathrm{mSv} / \mathrm{h}$ \\
\hline & Side & $5.4509 \mathrm{E}+02$ & $1.4535 \mathrm{E}-04$ & $5.4509 \mathrm{E}+02$ & \\
\hline & Bottom & $4.3233 \mathrm{E}+02$ & $1.1276 \mathrm{E}-04$ & $4.3233 \mathrm{E}+02$ & \\
\hline Disposal & Top & $8.7206 \mathrm{E}-02$ & 4.1045E-05 & $8.7247 \mathrm{E}-02$ & $\mathrm{mSv} / \mathrm{h}$ \\
\hline \multirow{2}{*}{ Canister } & Side & $8.5268 \mathrm{E}-00$ & $1.6102 \mathrm{E}-04$ & 8.5269E-00 & \\
\hline & Bottom & $1.2643 \mathrm{E}-01$ & $6.1649 \mathrm{E}-05$ & 1.2649E-01 & \\
\hline EBS & & 1.1500E-02 & 6.1700E-09 & 1.1500E-02 & Gy/h \\
\hline
\end{tabular}




\section{REFERENCES}

[1] Atomic Energy Bureau, "Statistical data related to nuclear power", Ministry of Education, Science and Technology, 2009.

[2] S. W. Park, "Why South Korea needs pyroprocessing”, Bulletin of the Atomic Scientists, Oct. 26, 2009.

[ 3 ] K. C. Song, H. S. Lee, J. M. Hur, J. G. Kim, D. H. Ahn and Y. Z. Cho, "Status of Pyroprocessing Technology Development in Korea", Journal of Nuclear Engineering and Technology, Vol. 42 (2), p. 131, 2010.

[4] J. G. Kim, K. R. Kim, I. T. Kim, D. H. Ahn and H. S. Lee, "Thermal Release of LiCl Waste Salt from Pyroprocessing", Journal of Korean Radioactive Waste Society, Vol. 7 (2), p.73, 2009.

[ 5 ] Pyroprocess Material Balance, Version 2.6.0, 2009.06.11 (2009)

[6] D. K. Cho, J. W. Choi, H. J. Choi and D. H. Kook, "Evaluation of Metal Waste Inventory from Pyroprocessing of PWR Spent Fuels for a Deep Geological Disposal System Design", Proceeding of Korean Nuclear Society 2010 Fall Meeting, Sep. 18, 2010.

[ 7 ] D. K. Cho, J. W. Choi, H. J. Choi and D. H. Kook, "Source Term Characterization for Structural Components in $17 x 17$ KOFA Spent Fuel Assembly", Journal of Korean Radioactive Waste Society, Vol. 8 (4), p.347-353, 2010.

[ 8 ] K. R. Kim, S. Y. Choi, D. H. Ahn, S. Paek, B. G. Park, H.
S. Lee, K. W. Yi and I. S. Hwang, "Computational analysis of a molten-salt electrochemical system for nuclear waste treatment", Journal of Radioanalytical and Nuclear Chemistry, Vol. 282, p.449-353, 2009.

[9] M. S. Lee, J. W. Choi and H. J. Choi, "Characteristics of pyroprocess wastes and its management", Proceeding of Korean Radioactive Waste Society 2010 Fall Meeting, 2010.

[10] J. Y. Lee, D. K. Cho, M. S. Lee, H. J. Choi and J. W. Choi, "The Geological Disposal Concepts for the Metal Wastes from Spent Fuel Recycling Process in Korea", Proceeding of the Korean Nuclear Society 2009 Fall Meeting, 2009.

[11] J. Y. Lee, D. K. Cho, H. J. Choi and J. W. Choi, "Concept of a Korean reference disposal system for spent fuels", Journal of Nuclear Science and Technology, Vol. 44 (12), p.1565-1573, 2007.

[12] J. Y. Lee, J. T. Jeong, D. K. Cho, D. H. Kook, M. S. Lee and H. J. Choi, "Conceptual Design of Complex Disposal System for Spent Fuel and Pyroprocess Wastes", Proceeding of Korean Radioactive Waste Society 2009 Fall Meeting, 2009.

[13] Jeremy E. Sweezy, MCNP-A General Monte Carlo NParticle Transport Code, Version 5, LA-CP-03-0245, Los Alamos National Laboratory (LANL), 2000

[14] SKB, "Deep repository for spent nuclear fuel", SKB TR99-06, 1999. 